\title{
IDEOLOGY, UTOPIA AND THE CRISIS OF POLITICS
}

\author{
by Guido Montani
}

In the following paper ${ }^{1} \mathrm{I}$ wish to explain the methodological approach that I adopted in the course of my latest research ${ }^{2}$ into the complex question of the relationship between ideology and social sciences. The main issue at stake here is understanding why the concept of ideology receives so little attention from social scientists, despite the fact that it is practically impossible to study political, social, legal and economic topics in any depth without coming across the question of ideology. Yet it is often summarily dismissed with the writer claiming not to adopt an ideological approach. This claim is absurd. As Max Weber ${ }^{3}$ says, " "to let the facts speak for themselves' is the most unfair way of putting over a political position to the student". Human relationships produce not only facts, but also interpretations of facts, as all scrupulous historians are aware. Edward Carr" notes: "The historian is neither the humble slave, nor the tyrannical master, of his facts. The relation between the historian and his facts is one of equality, of give-and-take. As any working historian knows, if he stops to reflect on what he is doing as he thinks and writes, the historian is engaged in a continuous process of moulding his facts to his interpretation and his interpretation to his facts. It is impossible to assign primacy to one over

Professor of International Political Economy, University of Pavia.

1 The first draft of this paper was presented on 28th November 2019 at the meeting of the Istituto Lombardo Accademia Scienze e Lettere.

2 G. MonTANI, Ideologia, economia e politica. Il federalismo sovranazionale come pensiero emergente, Pavia University Press. 2019.

3 M. Weber, Science as a Vocation, in H. H. Gerth, C. Wright Mills (eds), "From Max Weber", New York, Free Press, 1946, p. 29.

4 E. H. CARR, What is History?, London, Penguin Books, 1987, p. 29. 
the other". The same can also be said of the sociologist, the economist, the jurist, the political scientist and the anthropologist.

I would like to add a brief observation on the topicality of this debate. Since the second half of the last century there has been a growing consensus that we have seen the "end of ideology", so much so that even those active in politics sometimes falsely assert that their proposals have nothing to do with ideology. Though not the main cause, this conformist trend has had the consequence of reducing the scope and content of the programmes of democratic parties: their horizon is the next legislature, gaining power nationally. We cling to pragmatism to justify short-term proposals, overlooking the major issues, such as the crisis of the international order, nuclear rearmament and the environmental crisis - some of the threats hanging over the future of the human species. Yet the crisis of the international order after the end of the Cold War should have been a sharp wake-up call for our sleepwalking politicians. Firstly the break-up of the USSR, then the decline of America and the rise of new global powers such as China and India, showed that the old bipolar hegemonic order was being replaced by fierce competition between large and small powers that are increasingly using nationalism to justify their foreign and domestic policy. So why has the nationalist ideology come to dominate the international political scene once more, while other ideologies are retreating? It is a question that needs to be answered.

Let us first look at some theoretical aspects. We can start by considering an insightful essay of 1976 by Georg von Wright, a Finnish philosopher working in Cambridge who continued to develop the analytical approach to philosophy initiated by Wittgenstein. In an essay entitled "Determinism and the Study of Man", von Wright proposes studying the logic of intentional human action, an issue that is of little interest to natural sciences, such as physics, Darwinism and biology. "Human science is primarily a study of phenomena under the 'reign' of social institutions and rules"5. We can study our complex social reality by examining the intentional behaviour of a single individual. To do this, von Wright proposes a practical syllogism which he illustrates in the following way: "A wishes to do $p$ (go to the theatre tomorrow, for

5 G. Von Wright, Determinism and the Study of Man, in J. Manninen, R. ToumELA, "Essays on Explanation and Understanding", Dordrecht-Holland, Reidel Publishing, pp. 415-435; p. 415. 
example); A believes he cannot do $p$ if he does not do $q$ (book a ticket in advance, for example). So A is prepared to do q"6. We do not need to analyse this in depth: it shows how we take decisions for actions that will take place in the future, therefore in the course of a temporal process. It can therefore also be applied to history, and ideological thinking. In his essay von Wright observes that social laws are by definition subject to historical change, which thus means that 'Social 'laws' are not a generalization from experience but conceptual schemata for the interpretation of concrete historical situations.... On this account one can say that social study occupies an intermediate position between philosophy and history. It can move in the direction of the one or the other of the two poles, but it cannot live a self-contained life divorced from either of them"' need for ever closer collaboration between the different disciplines. Not to mention the developments in science and technology - information technology and biology in particular - as crucial determinants of social behaviour, given the increasing pace of technological progress and its repercussions on daily life. In studies on the origin of humanity, palaeoarchaeology has made amazing discoveries thanks to the carbon dating of fossils and the study of DNA from human remains.

Recently, another analytical philosopher, John Searle, has developed an important method for the study of intentional behaviour, formulating a series of convincing analyses ${ }^{8}$. Searle extends the study of intentional human behaviour from the individual to the community by flatly rejecting the methodological individualism that had been adopted by almost all of the social science community prior to then. As Searle says, "In collective intentionality, it cannot be required of each individual's intentionality that he knows what the intentionality on the part of others is. In complex forms of teamwork or collective behaviour, one typically does not know what the others are doing in detail. All one needs to believe is that they share one's collective goal and intend to do their part in achieving the goal"9. By way of example,

6 G. VON Wright, Determinism and the Study of Man, cit., p. 417.

7 G. VON Wright, Determinism and the Study of Man, cit., pp. 434-435.

8 J. SeArle, The Construction of Social Reality, New York, The Free Press, 1995; J. SeArle., Making the Social World. The Structure of Human Civilization, Oxford, Oxford University Press, 2010.

9 J. SEARLE, Making the Social World, cit., p. 45. 
we can take the behaviour of players in a football team. Each player carries out a certain role with the awareness that his performance is part of a pattern of collective behaviour with a specific purpose: to score a goal against the opposing team. Another example is the division of labour in a factory, where each worker performs a specific task, not necessarily the same as his fellow workers, but with the aim of producing a certain product. On the contrary, the behaviour of entrepreneurs who work towards achieving maximum profit cannot be considered collective behaviour, despite the fact that they share the same goal: their action is coordinated by the rules of the market but they do not necessarily need to coordinate with each other. "In order to engage in collective behaviour", observes Searle, "I have to believe (or assume or presuppose) that others are cooperating with me" 10 . In short, for there to be collective intentionality, there must be a common purpose, goal or ideal to achieve.

Now let's take a brief look at a second set of notions developed by Searle that are particularly useful for our investigation. I will focus on the relationship between collective intentionality and institutions. The importance of this relationship is underlined by the subtitle that Searle proposed for his book: "The structure of human civilization". In short, institutions are the "glue" that holds the whole of human society together as it evolves. Searle rightly asserts that language is the basis of this, as the institution fundamental to the creation of the whole complex system of interdependencies we live in: "You can have a society that has language, but does not have governments, private property or money. But you cannot have a society that has government, private property, and money, but does not have language" 11 . The particular nature of language enables humans to create institutions that distinguish them from all other living species. In the Palaeolithic era, homo sapiens was able to represent external reality in his mind (for example, to observe that there was a river blocking his path), and conceive a collective action with his companions (such as building a raft) to cross the river. "With the addition of linguistic syntax to animal intentionality we enable speakers to do something that no non-linguistic animal can do"12. Let's look at a simple example of how a human

\footnotetext{
10 J. SeArle, Making the Social World, cit., p. 53.

11 J. SeArle, Making the Social World, cit., p. 62.

12 J. SeArle, Making the Social World, cit., p. 79.
} 
institution can be established on the basis of the logical structure created by language. Let's imagine a wedding taking place between two individuals in front of a registrar or religious celebrant. Once the marriage has been celebrated with the customary vows, there will be legal consequences, rights and duties for the spouses. Searle indicates the logical formula of the new social commitments deriving from the rite of marriage and other institutions: "The rules typically have the form ' $\mathrm{X}$ counts as $\mathrm{Y}$ in $\mathrm{C}$ '. (For example, making such and such an utterance $\mathrm{X}$ in this context $\mathrm{C}$ counts as making a promise $\mathrm{Y}$ )" 13 . Another example could be: a 100 euro banknote $(\mathrm{X})$ has purchasing power which equates to (counts as) a certain basket of goods (Y) in the European Monetary Union (C). Human beings are thus able to modify the social reality they live in by creating institutions that allow them to regulate complex social relationships, such as the market, the church, universities, the state and relations between states. Institutions represent a form of power, deontic power. "According to the conventions of language, we already have a deontology. We already have commitments, in the full public sense that combines irreversibility and obligation. Language is the basic form of public deontology"14. To conclude: "All of institutional reality is created by Declarations ... But language itself is not created by Declaration"15.

Once we have clarified the relationship between individual intentionality, collective intentionality and the creation of social institutions, the glue of civilization, we can turn to the role of ideologies in society and in the social sciences. Let's remember the 'practical syllogism' which describes the relationship between means and ends, i.e. if I want to go to the theatre tomorrow, I have to buy a ticket. If we look at the great ideologies of the modern era, namely liberalism, democracy, socialism and nationalism, without going into great detail we can make out the relationship between the essential, or primary value characterising each modern political ideology, and the institutional means by which its exponents sought, or seek, to accomplish that value. I have indicated only four ideologies in order to simplify the discussion, perhaps excessively so. Yet it is not difficult to apply these concepts to a wide range of political parties that pursue

13 J. SeARle, Making the Social World, cit., p. 81.

14 J. SEARLE, Making the Social World, cit., p. 82.

15 J. SeArLe, Making the Social World, cit., p. 110. 
combined programmes, such as Christian-socialist parties, liberalsocialist parties, liberal-conservative parties, national-socialist parties, etc. The four ideologies that I have listed are grouped together for simplicity under the label 'traditional ideologies'. I believe that they merit this definition because they characterized modern history, with the first manifestations of English liberalism and the Glorious Revolution, and subsequently with the ideologies that rose powerfully to the fore during the French Revolution and the Industrial Revolution.

The development of liberalism is common knowledge. It is often traced back to when the aristocracy and richer members of the nascent bourgeoisie claimed rights from the divinely-appointed sovereign. This stage is described as being one of negative rights, that is, individual freedoms being claimed from the coercive power of the state. It was followed by that of positive freedoms because, as Guido De Ruggero says, freedom is not free will "but man's ability to determine his destiny... any natural or compulsive dependence is denied and what takes its place is what our awareness of our duties towards ourselves and others spontaneously suggests to us" 16 . In this way the nature of the state changes: "the state, the definitive organ of coercion, becomes the maximum expression of freedom; the traditional enemy of individuals models itself in the form of individual consciousness" 17 . In this process of transformation of the state, with the recognition of positive freedoms alongside negative ones, the symbiosis between liberalism and democracy was also perfected (Searle's context C). The most evident and precise manifestation of this happy and inevitable marriage was probably that described by John Stuart Mill in two essays: On liberty, published in 1859, and Representative Government, published in 1861. In contemporary political language it has become customary to frame liberal democracy as a form of government that guarantees citizens a series of fundamental rights and their full participation - without distinction of class, wealth, sex, culture, ethnicity or religion - in the formation of government, which can only be considered representative if it has the explicit consent of citizens.

With regard to socialism, if we take into account its early expressions represented by the ideas of Saint-Simon, Fourier and

${ }^{16}$ G. De Ruggero, Storia del liberalismo europeo, Milano, Feltrinelli, 1962, p. 339.

${ }^{17}$ G. De Ruggero, Storia del liberalismo europeo, cit., p. 339. 
Owen, its primary value can be identified as social justice, arising from criticism of the exploitation of factory workers and the unsanitary conditions in the urban agglomerations they crowded into. However, in the Communist Manifesto of 1848, Marx and Engels lambasted the ideas of the first socialists as utopian, and indicated communism as an alternative. They based their analysis on the class-based division of society and the formation of a global capitalist market as the material basis of our social existence (context C). As an alternative to the capitalist organization of production they proposed the abolition of private ownership of the means of production, by means of a violent revolution that would put an end to the power of the bourgeoisie. For Marx and Engels, the state was none other than business arm of the bourgeoisie. How history played out, in the second half of the nineteenth century and the first decades of the twentieth century, is well known. Part of the workers' movement chose the parliamentary, democratic path to increase and consolidate the power of workers in the state, as happened with German social democracy. Another part of the workers' movement chose the path indicated by Lenin to seize power in Tsarist Russia, with the subsequent creation of the USSR, the workers' homeland.

We do not need to go into the developments of liberalism, democracy and socialism in any more detail. For my purposes, which indirectly also concern the extra-European developments of the four ideologies, it will suffice to briefly indicate the relationship between the primary values of these ideologies and the means that the various parties and governments conceived and implemented to achieve them. The only issue that remains to be tackled is the relationship between the three traditional ideologies and nationalism. The development of nationalism appears to be similar to that of the other three ideologies, but its relationship to their values is complex and murky. If we look at the embryonic phase of nationalism, namely the people's movements that led to the unification of Italy and Germany, we find a mindset that succeeds in bringing together nationalism and cosmopolitanism. Mazzini founded 'Giovine Italia' and 'Giovine Europa' almost simultaneously, in the belief that once Italy was freed from the oppression of the Austrian Empire, and equipped with a republican form of government, the issue of the peaceful coexistence between European nations would automatically be solved: there being no reason for war between republics with governments elected by the people. 
Mazzini's perspective was also shared by many democrats who were his contemporaries, and the liberal-democratic ideology of international relations is still widespread today (think of Fukuyama's 'End of history': the triumph of international liberal-democracy after the end of the Cold War). In Germany, in the same period when Mazzini was embarking on his revolutionary enterprise, Friedrich List proposed the unification of the German market - subsequently achieved with the Zollverein - as the first step towards the political unification and industrialization of Germany. English manufacturing was churning out products so cheaply that Germany struggled to establish its own industry. The theorist of the nascent industry proposed protectionism as a temporary solution, until German industry found its feet on the world market. In his view, once this had been accomplished, the process would lead to the formation of a vast cosmopolitan market of free, peaceful nations.

How nationalism subsequently developed is common knowledge. Once the industrial revolution spread from Great Britain to all other European nations and the United States, a fierce race to conquer the colonies began, which led to traditional parties - liberals, democrats and socialists - becoming the accomplices of the politics of national power. The leaders of these parties did not understand the nature of a process that was leading Europe's peoples towards a catastrophe ${ }^{18}$. The liberals and the socialists proved unable to react to the early symptoms of a policy that quickly degenerated into a clash between the major powers on the battlefields of the First World War. The European nation states had integrated all the existing social categories: the ruling classes, the petty bourgeoisie, the workers and other public and private sectors. A compromise between liberalism, democracy and socialism had been achieved. Now the people were truly united in the state, but this state, which proclaimed itself sovereign, conceived international relations as an arena of conflict, where military force was the only way to defend national independence (the primary value of nationalism). To affirm its primacy, the nation state asked its citizens to die in defence of their homeland. The history of this period abounds with accounts of individuals united by common cultural, religious and political values,

18 On the relationship between liberalism, socialism and imperialism, see G. MoNTANI, Ideologia, economia e politica. Il federalismo sovranazionale come pensiero emergente, cit., Chapters 2 and 3. 
as evidenced by the years of the Belle Époque, when the arts flourished across Europe, huge progress was made in the natural and social sciences and philosophy, and the first forms of supranational organizations, such as the international workers' movements, came into being. Yet only a few years later the very same people who shared this long period of peace found themselves fighting on opposite sides. Right or wrong, my country. Nationalism is a modern form of religion to which altars are raised and human victims sacrificed; nationalism has supplanted the religious sentiment that dwells in every human being, transforming it into an instrument of power.

Many scholars, such as Carr ${ }^{19}$, view the 1920s and 1930s as a tragic sequence of political, economic and social crises that culminated in the Second World War, a second immense catastrophe. The images of the rubble of devastated cities, the atomic bombs dropped on Hiroshima and Nagasaki, Auschwitz and the other death camps remain indelible not only in the minds of those who lived through those times, but also the subsequent generations. How could all of this have come about? How did the spiritual legacy of humanism, the Renaissance and the Enlightenment and the idea of human progress end up generating "absolute evil"?

We need to search for an answer to these questions and, to this end, it can help to gain further insight into ideological thinking. As briefly mentioned with regard to the structure of the traditional ideologies, we can comprehend that there is not an unequivocal relationship between the aims of intentional collective action - the values of freedom, political equality, social justice and national independence - and the means for achieving those aims, but rather a wide margin of interpretation and uncertainty (context $\mathrm{C}$ ). The task of a party or statesperson is to lead a community into an uncertain future, because the path that humanity intends to take cannot be deduced from a precise model, from rational knowledge, as scientists do with nature. As von Wright observed, the social sciences cannot help but see themselves as an intermediate field of knowledge with regard to other disciplines such as history and philosophy (as well as natural sciences and technology). For this reason, social scientists must acknowledge the limits of their professional arena. Max Weber rightly made a clear distinction between

${ }^{19}$ E. H. CARR, The Twenty Years' Crisis, 1919-1939. An Introduction to the Study of International Relations, London, Macmillan, 19391, 1981. 
active politics and the study of human behaviour. "Politics has no place in the lecture room... the prophet and the demagogue have no place at the lectern" 20 . Active politics and the study of political behaviour are two separate professions. Exceptionally, they might coincide during the developmental stages of a political ideology, as was the case with Thomas More, Locke, Mazzini, List, Marx and Lenin.

The first important contribution to understanding ideological thinking was Marx's discovery of the phenomenon of false consciousness. His critique of liberal thought, and capitalism in particular, is well known and does not need to be repeated here. Yet it seems reasonable to assume that all ideologies run this risk, and that Marxism was certainly no exception, as the history of the USSR shows, especially in the Stalinist phase, when the truth propagated by the regime was defended from criticism by imprisoning, torturing and killing the 'enemies of the people'. The risk of false consciousness is a permanent characteristic of political thought, and it can be mitigated, but not completely eliminated, with the help of the social sciences and if governments pledge not to use physical violence or intimidate opponents. The relationship between politics and violence is therefore the issue which needs to be investigated in more depth, because despite the progress made in every field of knowledge and civil life, violence continues to be an ugly part of our social existence, both among individuals (even in the family) and between human communities (black and white, male and female, believers and non-believers, ethnic group A and ethnic group B, etc.), and between states. Philosophy, with the help of the social sciences, is now increasingly dealing with the multifaceted issue of violence ${ }^{21}$.

In my opinion, politics can make a decisive contribution to the creation of a society where individual relationships can be emancipated from violent impulses and political power that foments them. To this end I believe it is useful to look at the recent developments in international politics, following the end of the Cold War. The post-war period saw a world system dominated by two superpowers, the US and the USSR, a situation which, for better or for worse, ensured a long period of international stability, albeit not without tensions between the two powers and in their respective areas of influence, with dissent

${ }^{20}$ M. Weber, Science as a Vocation, cit., p. 20.

${ }^{21}$ L. Magnani, Understanding Violence, Berlin, Springer, 2011. 
sometimes repressed by force. Yet the balance of terror (MAD) prevented this bipolar system of world governance from degenerating into open warfare. The fall of the Berlin Wall opened up a crack through which nationalism seeped back in, both in the former Soviet bloc countries and former Yugoslavia, where a horrified, incredulous European Union witnessed the return of concentration camps and ethnic cleansing on its doorstep. In the early decades of the twentyfirst century it became clear that the Us was no longer able to act as the 'stabilizer' of the international order. New major powers have emerged, such as China, India, Brazil, and Russia itself, determined to regain its leading role of the past. In short, the new international political scene is now heading towards a multipolar arrangement dominated by great powers seeking to establish their own primacy: 'America First', along with 'China First', 'Russia First', etc. Moreover, as the history of the last century teaches us, power politics has to be based on strong internal cohesion and external military strength. In the Us white supremacy is gaining ground once more; China is pursuing a policy of ethnic homogenization in favour of the Han ethnic group, persecuting the Uighur minority; in India the Muslim population suffers at the hands of the Hindu majority, and in Africa and the Middle East the constant ethnic and religious conflicts have often led to genocide. If we factor in the race for new atomic weapons announced by Putin and Trump, we can observe a worrying rise in international tension, similar to the conditions that led to the First and Second World Wars. The fact that second generation nationalism is still in its early stages does not mean that it is any less dangerous than its predecessor. Nationalism is a deadly disease that needs to be tackled before it is too late.

I do not intend to go into an in-depth discussion of the causes of the crisis of the international order and the explanations for it that are emerging, which are substantially based on the traditional conception of international relations: some hope for a return to a liberal-democratic order, restoring multilateralism, while supporters of Marxist and socialist ideas aim to achieve a more just international order by taking greater control - nationally - of finance and multinational companies. There is no need to elaborate on this here ${ }^{22}$. I will focus instead on the

\footnotetext{
22 Those interested in this topic can consult: G. MonTANI, Supranational Political Economy. The Globalisation of the State-Market Relationship, London and New York, Routledge, 2019, Part I.
} 
line of argument adopted in this address regarding the role of ideologies in political thought, in the belief, or hope, of indicating an effective course of action. I will attempt to show that the international political debate must take the issue of the future of humanity into consideration, because world powers cannot be allowed to wilfully conceal the fact that we are now entering a new stage in the nuclear arms race, governed by extremely insecure systems of control based on artificial intelligence. Alongside this threat, of course, there is climate change and the sixth mass extinction of living species, including our own. The horizon of the debate must therefore be pushed beyond the limits imposed by politics based on the nationalist ideology and an international order open to military, economic and technological clashes between large and small powers. We need to consider the cosmopolitan perspective as an alternative to second generation nationalism.

This is no utopia, in the sense of a pipe dream. I consider myself a realist and I operate as much as possible in the arena of political realism that can be traced back to Machiavelli. I will therefore now consider two new ideologies, compared to the four I termed 'traditional ideologies'. These ideologies arose and established themselves after the Second World War, the first as a response to the great catastrophe and the second in reaction to the growing damage inflicted by industrialisation on the planet's natural resources: in other words, European supranational federalism and environmentalism or ecologism.

It was during the Second World War that the political unification of Europe was envisaged as the way forward by two pioneers, Jean Monnet and Altiero Spinelli, one of the authors of the Ventotene Manifesto (1941). Jean Monnet went on to play a crucial role in the creation of the first supranational political community, the ECSC (the European Coal and Steel Community), and Spinelli played an equally crucial part in transforming the European Community into a federation. While Monnet focused the attention of politicians and governments on a strategy of partial reforms, in little steps, an approach now supported in all European circles, Spinelli based his strategy on moving beyond the absolute sovereignty of the European states, by means of a constituent assembly. The crux of the Ventotene Manifesto is: "The dividing line between progressive and reactionary parties no longer follows the formal line of greater or lesser democracy, or of more or 
less socialism to be instituted; rather the division falls along the line, very new and substantial, that separates the party members into two groups. The first is made up of those who conceive the essential purpose and goal of struggle as the ancient one, that is, the conquest of national political power - and that, although involuntarily, play into the hands of reactionary forces, letting the incandescent lava of popular passions set in the old moulds, and thus allowing old absurdities to arise once again. The second are those who see as the main purpose the creation of a solid international state; they will direct popular forces towards this goal, and having won national power, use it first and foremost as an instrument for achieving international unity". The dividing line of the Ventotene Manifesto has not always been consistently followed by European federalists in the continent's various countries, but it was certainly the primary source of inspiration for the Italian federalists, who played a central role in the evolution of federalist strategy in the European Union ${ }^{23}$. It is true that the European Union remains an unfinished federation, but it cannot be disputed that some of its institutions, such as the European Commission, the Court of Justice, the European Parliament and the European Central Bank are genuine federal or supranational institutions. Imperfect as it is, the European Union is the world's only supranational institution, and in the context of the serious crisis of international politics we are now experiencing, it can play a leading role in the construction of a new, peaceful international order.

The second school of thought that rejects nationalism, though not always consistently, is environmentalism or ecologism. The environmental movement first emerged in the 1960s in English-speaking countries, gradually growing and gaining political power in the national institutions of some important European countries, such as Germany and France, as well as in the USA, in the ranks of the Democratic Party. The situation has changed in more recent times, when, thanks to the frequent UN conferences on global warming and the anguished appeals of scientists and the youth protest movement, the environmental issue has finally come to the attention of world politics. The ideology of environmentalism has had many precursors and theorists. I will mention

${ }^{23}$ With regard to the ideas of the Italian federalists, see M. AlBertini, War Culture and Peace Culture, in M. AlberTini, (ed. G. Montani), Nationalism, Federalism and European Integration, Soveria Mannelli, Rubbettino, 2017. 
just two important analyses. The first is that of Hans Jonas, The Imperative of Responsibility ${ }^{24}$, published in German in 1979, which examines the relationship between human nature, technology and the environment from an ethical point of view, and which proposes the 'principle of responsibility', i.e. the commitment that each individual and each generation must make to ensure life on our planet (the primary value of environmentalism) remains possible for the generations to come. It was on this basis that the concept of 'sustainable development' was subsequently formulated; a concept that has now been adopted by almost all scholars in both the social and natural sciences, as the guiding principle of environmental strategies. The environmental movement has benefited from the advent of the UN conferences as an organizational platform. Today, the Sustainable Development Goals are a point of reference for all governments and politicians who intend to address environmental issues seriously. The second writer who has contributed to the development of an environmental ideology and ethics is Stephen Gardiner. His analysis effectively shows how national governments pass the costs of environmental policies onto future generations, instead of tackling the problems themselves, as they should, to avoid them impacting on their successors. To quote from his conclusion: "Most prominently, climate change is one of a number of contemporary global problems that casts doubt on the traditional philosophical strategy of constructing basic justice on the model of a single self-sufficient nationstate. If we have truly entered a new epoch on the earth, a geological era dominated by humanity - the anthropocene - then such a model seems at least seriously incomplete, and perhaps hopelessly outdated. Theorists should ask whether this requires revising their grand visions of ethics and justice" 25 .

We can now take the last step towards the end of this long address. It is useful to discuss the various ideologies, whose primary values - an attempt to say the unsayable, according to von Wright - manifest themselves over the passing of time, and, as the practical syllogism suggests, can coexist, not without clashes or conflicts among their

${ }^{24}$ H. JonAs, The Imperative of Responsibility. In Search of an Ethics for the Technological Age, Chicago, Chicago University Press, 1984; eng. trans. of Das Prinzip Verantwortung, Frankfurt am Main, Insel Verlag, 1979.

${ }^{25}$ S. Gardiner, A Perfect Moral Storm. The Ethical Tragedy of Climate Change, Oxford, Oxford University Press, 2011, p. 435. 
supporters, to implement the policies and institutions that are needed to translate them into reality. Now let's look at the relationship between ideology and utopia, as Karl Mannheim did ${ }^{26}$. Mannheim was the first modern scholar of this phenomenon, but he took a different approach from political scientists, whose studies are preferably dedicated to ideology alone. The reason why it is useful to discuss the relationship between the two concepts is explained very effectively by the philosopher Paul Ricour, who underlines the ill-advised haste with which many have accepted the notion of "the death of ideologies, thus giving up on any kind of plan for society. But surely it is worth holding onto certain ideas supported by these utopia visions of a better future, that of 'perpetual peace' for example, in the sense intended by Kant or Fichte? It is not enough, like Jean-François Lyotard, to say that the 'grands récits' of emancipation are over, or like Fukuyama, announce 'the end of history'. It is not just that these are prospects born out of despair; what about that aspect of planning without which no political action can be taken?"27.

If we consider the long-term aims of the aforementioned two modern ideologies, a cosmopolitan horizon can be glimpsed in both. With regard to the 'dividing line between progress and reaction' described in the Ventotene Manifesto, the final goal is not just the creation of the United States of Europe, but 'a solid international state' which is not necessarily European. Indeed, the Ventotene Manifesto also briefly mentions the creation of a world federation, in a distant future, thus echoing Kant's notion of 'perpetual peace'. With all of the UN's shortcomings, in particular that of basing international relations on the absolute sovereignty of nation-states, and therefore on armaments and war, in 1948 it approved the Universal Declaration of Human Rights. Yet guaranteeing these rights has been left up to national governments: there is no supranational court to which the citizens of the world can apply to ask for justice against an oppressive power. So how should the UN be reformed? It is feasible to imagine that the European Union, which approved its own Charter of Fundamental Rights of the European Union, and which has established 'European citizenship', granting all its citizens the right to study, work

${ }^{26}$ K. MANNHEIM, Ideology and Utopia, London, Routledge, 1953; Eng. trans. of Ideologie und Utopie, Cohen, Bonn, 1929.

27 P. Riccur, Philosophie, étique et politique. Entretiens et dialogues, Paris, Seuil, 2017, pp. 116-117. 
and circulate in all countries of the Union, might work to extend similar rights to all of the planet's inhabitants. Many of today's young people already think and act like citizens of the world. The EU could become the driving force behind a cosmopolitan reform of the right of citizenship, for the recognition of the legal status of citizen of the world.

Environmentalism also presents a similar cosmopolitan horizon. It would make no sense to fight to defend the natural world in a single country. Air and water pollution knows no boundaries, just as modern communication channels, infections and the extermination of animal and plant species know no boundaries. We cannot resign ourselves to the end of life on the planet. Nation states came into being to defend life, to protect their citizens against internal and external threats. Yet nation states are no longer capable of fulfilling this primary task. Edgar Morin is right when he says: "There is no civilization that does not have a base layer of barbarism. Since barbarism is an ingredient of civilization, all we can do is resist it, not suppress it. Humans reveal their best or their worst at times of crisis, conflict and disaster" 28 . We must react to the crisis, to the inertia of national governments. Many intellectuals and politicians "are unaware that the community of fate that unites all humans on this Earth-Homeland calls for a shared consciousness of that earth/homeland, a consciousness that encompasses all homelands without suppressing them"29. To rein in the vestiges of barbarism that lurk in human nature, our Earth-Homeland must be inhabited by citizens of the world.

We can now repeat the same exercise for the four traditional ideologies we discussed above. The long-term goal of liberal democracy could be said to be a world state of law governed by a democratic 'governance'. On 19th September 2012 the UN approved a Declaration on the Rule of Law at the National and International Levels. The Declaration is commendable for the principles it lays out, but - as is the case with other UN Declarations - the final responsibility for ensuring its implementation rests with national governments. No supranational 'power' is foreseen, meaning that any breaches of the rule of law by national governments cannot be punished. When it comes to socialism and communism, the discussion is more complex. By way of example, Jonas said that the Marxist utopia is a classless

${ }^{28}$ E. Morin, Connaissance, ignorance, mystère, Paris, Fayard, 2017, p. 93.

${ }^{29}$ E. Morin, Connaissance, ignorance, mystère, cit., p. 144. 
society. Yet after the failure of the USSR and the experiment of abolishing private ownership of the means of production, any proposals for achieving social justice have to take history into account. China, for example, has a government that declares itself communist, but has embraced the capitalist system as a vehicle for its redoubtable economic development. Perhaps, for our purposes, we can say that the goal of socialism is a cosmopolitan society that, within states that respect the principles of liberal-democracy, reduces wealth inequality among its citizens to a minimum, promoting effective policies to combat poverty and cut working hours.

Now we can turn to the nationalist ideology. As we have seen, this ideology too had a utopian phase with Mazzini and List, with the hypothesis that a world of peaceful nations open to free international trade was possible. This utopia however clashed with the harsh reality of power politics and the degeneration of the national ideal into hatred between peoples, which reached its peak with the First and Second World Wars. Today, if we wish to indicate the end point of a world populated by sovereign states fighting for world supremacy, the outcome is Auschwitz or, worse, a nuclear holocaust and the end of the human species. There is no positive utopia for an ideology that is based on animosity between friends (compatriots) and enemies (foreigners), and the manufacturing of deadly weapons to exterminate opponents. In the age of planetary social interdependence, the global market and the global information technology network, to argue that national peoples must remain closed within their national borders means destroying the material basis of our well-being and civilization. Second generation nationalism is a dystopia, an ideology that cannot conceive a future for humanity.

My conclusion is therefore that the ideologies of liberalism, democracy and socialism that were inspired by the ideals of humanism and the Enlightenment can, if they so wish, embrace the ideal of progress indicated with great clarity in the Ventotene Manifesto. The European Union is already following this path, and environmental movements and parties are following it too. I have no illusions about the difficulties that will have to be overcome. These include not only national interests, which prevent governments from clearly perceiving what they need to do to guarantee the future of the planet, but also the ideological resistance expressed by intellectuals to this new idea of progress. I can offer a number of examples drawn from recent studies by well-meaning humanists and defenders of the ideals of the Enlightenment. Steven 
Pinker asserts: "Many scientists are naïfs when it comes to policy and law, and cook up nonstarters like world government ... and escaping a befouled Earth by colonizing other planets" ${ }^{30}$. Pinker does however make some judicious observations elsewhere, such as "Nothing in human nature prevents a person from being a proud Frenchman, European, and citizen of the world all at the same time" 31 . But can we be citizens of the world in states equipped with weapons for mass extermination and willing to go to war? Is this human condition compatible with the humanistic ideals that Pinker defends with so much energy, precision and competence? Another example is the philosopher Kwame A. Appiah who, in his essay Cosmopolitanism, writes: "There are a few political cosmopolitans who say they want a world government. But the cosmopolitanism I am defending prizes a variety of political arrangements, provided of course, each state grants every individual what he or she deserves. A global state would have at least three obvious problems. It could easily accumulate uncontrollable power, which it might use to do great harm; it would often be unresponsive to local needs; and it would almost certainly reduce the variety of institutional experimentation from which all of us can learn" 32 . Yet Appiah lives in the United States, a federation with fifty member states which continue to retain their independence despite the presence of a central government; a union of states with the motto Unity in Diversity, whose citizens continue to enjoy fundamental freedoms. Then there is the example of the European Union, where, though discussions on relations between national governments and the powers of the Union are interminable and often heated, it certainly cannot be said that the supranational powers of the Union stifle the freedom of European citizens. Lastly we come to Tzvetan Todorov, who says that the European Union's member states defend an idea of civilization that incorporates fundamental values and rejects the barbarism that would deny those values. But he adds that "the individual can only claim his rights to the extent that a state guarantees them and, if necessary, intervenes to defend them. We can feel deeply

30 S. Pinker, Enlightenment Now. The Case for Reason, Science, Humanism and Progress, London, Penguin Books, 2018, p. 390.

${ }^{31}$ S. PInKer, Enlightenment Now. The Case for Reason, Science, Humanism and Progress, cit., p. 450.

32 K. A. Appiah, Cosmopolitanism. Ethics in a World of Strangers, London, Penguin Books, 2007, p. 163. 
cosmopolitan in our souls, but we are never citizens of the world"33. Yet Todorov strongly condemns Nazi-fascism and its horrors. But he does not ask himself why the European Union of today is so different from the Europe that gave rise to those regimes. Cosmopolitanism cannot be reconciled with a world in which national governments practice power politics and defend the principle of national supremacy over other peoples. The tangible proof of this is that in Europe, the sun has set on the old conception of relations between national peoples: a number of powers - not all, of course, but above all those which could be the cause of violent conflicts between states - have been entrusted to a supranational Union.

To conclude, despite all the difficulties and objections that I have mentioned here, I am convinced that the political struggle to guarantee humanity a future of peace, and economic and political cooperation for the salvation of the planet, can be won. The will to live is the first defence of life. The young people now protesting together across the continents show that the ideals of humanism and the Enlightenment are rooted in contemporary world culture. These ideals unite the youth now taking a stand against the inertia of national governments.

\begin{abstract}
Riassunto - I partiti politici che si ispirano ai valori del liberalismo, della democrazia e del socialismo non riescono più a concepire un progetto di lungo periodo per i propri concittadini e per l'umanità. Dopo il crollo del Muro di Berlino, grandi e piccole potenze hanno avviato una sordida lotta per la supremazia mondiale, alimentando conflitti locali e globali, e il ritorno del nazionalismo come ideologia dominante. In questo saggio si intende mostrare che la tesi sulla "fine delle ideologie" è infondata: le ideologie tradizionali sono incapaci di progettare un futuro di progresso perché subiscono passivamente 1'ideologia della sovranità assoluta degli stati e della guerra giusta per difendere gli interessi nazionali. Il futuro dell'umanità è minacciato
\end{abstract}

da una nuova corsa agli armamenti nucleari e convenzionali, ai quali i governi dedicano immense risorse, che dovrebbero invece servire per salvare il Pianeta dal surriscaldamento climatico, dallo sterminio della vita animale e vegetale e dalle pandemie. La via intrapresa dai popoli europei, con la costruzione della prima Unione sovranazionale della storia, dovrebbe ispirare anche le politiche necessarie per la costruzione di un ordine mondiale fondato sulla cooperazione pacifica tra stati e l'avvio di politiche che si propongano di consentire ai cittadini del mondo di godere dei medesimi diritti di libertà e solidarietà che, seppure imperfettamente, si sono realizzati in Europa. Il progresso dell'umanità è un'utopia positiva che può diventare realtà.

33 T. Todorov, La peur des barbares. Au-delà du choc des civilisations, Paris, Laffont, 2008, p. 126. 